\title{
The interactivity of the landscape space and interiors in the architecture of the Latvian education and art buildings of the $20^{\text {th }} / 21^{\text {st }}$ century
}

\author{
Aija Grietēna, Aija Ziemel̦niece, Una Īle, Latvia University of Agriculture
}

\begin{abstract}
The article summarizes a small part of the research material, which considers the context search of the landscape space, architecture, and the indoor space in the architecture of education and art buildings. The schools and art buildings built at the turn of the 20th/21st century awarded with the Prize of the Year at the Latvian Architecture Best Works Award are used in the research. The context of the language of architecture and landscape space is formed by the knowledge of interdisciplinary directions of science that essentially affect the ecological, visual, visually aesthetic, and economic indicators. Studying more closely at this, this is also true of the aesthetic-psychological interactions among landscape architecture, architecture, and interior design, which are achieved in building sites with widespread glazed facades. Thanks to today's highly advanced construction technology capabilities, the visual transparency and illusory ease of buildings are increasingly able to create visual interconnections among the landscape space, architectural form creation, and interior.
\end{abstract}

Key words: indoor/outdoor harmony, landscape architecture, architecture, interior, glass systems.

\section{Introduction}

At the Latvian level, as well as at the global one, environmentalists, in their practices experience an increasing need for interdisciplinary co-operative planning, and we all, as environmental users, in our routinely day-to-day activities are pursuing the integrity and harmony of the environment [1-4; 6-19]. It is supported by the growing use of transparent, wide exterior glazed planes in architecture, which with a new, illusory, and plastic architectural form creation is clearly evident in the modern architecture of Latvian education and art buildings at the turn of the $20^{\text {th }} / 21^{\text {st }}$ century. This tendency is also evidenced by the results of the annual major architectural and construction competitions in Latvia for the last 25 years [12].

The modern education and art buildings in the contemporary Latvian landscape are characterized by higher multifunctionality and transformability than they had before. The new technological possibilities promote a wider creativeness of the environment makers, creating a higher degree of synthesis of architecture with landscape architecture, interiors, design, and other creative disciplines. By combining the visual interconnections among the landscape architecture, form creation of building volumes, and the indoor space, there are more opportunities and freedom to form creation. Therefore, today the environment makers and users are in front of the opportunity and responsibility by visually linking the landscape space with the indoor space through widely glazed translucent planes in architecture.
With the increase of the general level of education in aesthetics, ethics, and ecology of Latvia's society, nowadays it is increasingly involved in various environmental development processes through public comments. Due to the social sensitivity of sites and their widespread public character, the aspect of the integrity of architecture, the interior, and landscape of the educational and artistic buildings is often sparked by a wide public resonance. In order to create the integrity and harmony of the environment, opening the indoor space to a mutually qualitative interaction with the landscape requires an appropriate theoretical basis, which is manifested through scientifically sound mechanisms for the adjustment of urban environmental processes. Currently, the theoretical basis consists of a set of separate aspects $[4 ; 10]$.

Professor I. Strautmanis wrote about the lack of the environmental quality in Latvia in his publications in the last century, reflecting the results of research carried out [9]. But today 'the technical possibilities of the architects' creative work have changed, the range of materials and technological equipment has expanded but the quality of the environment is improving slowly. Due to the restoration of the private land ownership, harmonious planning of the urban environment is very difficult. The desire of entrepreneurs and investors to obtain the most favorable place in the city at all costs and to earn money with architecture also often improves not only the overall visual image of the environment, but, on the contrary, generates regular "shoe box" displays along the city's important highways. Architecture is 
increasingly losing its stagnant quality over the course of the century, becoming more and more illuminated and dummy. Today, the informational and emotional potential of architecture is a completely unattractive and undervalued quality. An in-depth research is needed to create a common platform for a dialogue between architects and designers in the light of the recent scientific discoveries [10].

The aim of the research is to determine the factors contributing to the psycho-emotional quality of the landscape space and interiors in the art of building the environment in the architecture of the Latvian education and art buildings that arose at the turn of the $20^{\text {th }} / 21^{\text {st }}$ century, studying the experts' highly rated three concert halls, two libraries, and eight educational buildings.

\section{Two tasks are ancillary to the aim:}

- to evaluate the interaction of the landscape space and the indoor space in the context of the socially sensitive typology of the public education and art buildings in the architecture of Latvia, created at the turn of the $20^{\text {th }} / 21^{\text {st }}$ century;

- to formulate harmonious interaction factors of landscape space and interiors in the art of building the environment of architecture of the Latvian educational and art buildings, in their typological context.

The theoretical and practical significance of the work is the formation of psycho-emotionally more harmonious and high-quality spatial environment in Latvia, through better cooperation between architects, landscape architects, and interior design specialists.

In practice, andscape architects, successfully cooperating with architects, interior designers, and designers, have been able to create a number of artistically high-value environmental sites that are characterized by the integrity or wholeness of the environment, thus fragmentarily improving the quality of our urban landscape space. In cooperation with Latvian and international experts, three concert halls, two libraries, eight educational buildings have been especially appreciated in this regard, analyzing of which, knowledge is obtained that in the future could be used in the art of creation of the environment, as well as in the interdisciplinary cooperation to create a high-quality environment.

\section{Materials and Methods}

The subject of the research is the interaction of landscape space and interiors in the architecture of Latvian education and art buildings at the turn of the $20^{\text {th }} / 21^{\text {st }}$ century, passing through wide glazed, transparent outer planes of the building volumes within the visual linking boundary (Fig. 1).

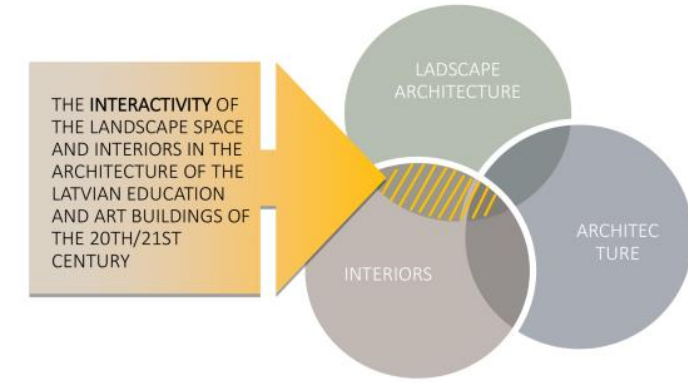

Fig. 1. The visual-aesthetic and psychological interaction of the landscape space and interiors [created by the authors, 2016]

\section{Research methods:}

The empirical and comparative analysis - for surveys of educational and art buildings in nature (for photo-fixing, analysis of interaction factors according to common criteria), interview collection and analysis, clarifying the opinions of experts, specialists in the sector of the society, spatial planning, and architecture, as well as social respondents about the interaction between the outdoor space and the indoor space in the context of typology of the education and art buildings in the architecture of Latvia, which dates back to the turn of the $20^{\text {th }} / 21^{\text {st }}$ century.

The graphically comparative and inductive cognition method, determining the factors contributing to the psycho-emotional quality of the landscape space and the indoor space interactions in the art of building the environment in the architecture of the Latvian education and art buildings.

\section{The application of the comparative method in} summarizing information for the research:

1. Principles of the glass system application in architecture:

- Composition of glass panel areas in space and their proportion - massiveness in relation to parts without glass.

- Compositional application of colors and chiaroscuro under the insulation impact.

- Research of visual accents created by the chiaroscuro play.

- Assessment of the semantic correspondence of indoors/outdoors and level of emotionality according to the functional program of the respective space.

2. Summary of studies on the impact of the mutual compositional build of indoors/outdoors:

- Architectural shape-building, glass systems, and the landscape around sites as the main criteria in the search for harmony between indoors and outdoors, compliance with the supreme spiritual task following the function of spaces.

- Assessment of the indoor/outdoor harmonysummary of opinions of experts and other respondents on correspondence of the 
indoor/outdoor dialogue to the supreme task of a site under consideration.

In the analytical generalization phase, the priority factors of the outdoors/indoors harmony were determined by virtue of the inductive cognitive method.

\section{Results and Discussion}

The research covers the best (winning) architectural sites of Latvia in the typological context of the educational and art buildings but in reality, there are many times more harmonious, remarkable sites in Latvia, so narrowing the boundaries (Table 1) has been set in order to preserve consistency in the quantity and quality of the selection of sites. The site research uses the matrix described in the introduction, which includes both an analytically descriptive situation analysis and a psycho-emotional quality assessment of interactions.

As the first of the criteria, the use of glazed area compositions and proportions in relation to the nonglazed parts in the interior were analyzed. An excellent example of the proportionality of glazing, with the integration of the urban landscape into the ballet hall and the lobby, wide stairs along the outer glazed inner wall of the southeastern facade raise the visitor's sight points at several levels above the city's roofs (architect Volker Giencke) is the interior of the Concert Hall "Lielais Dzintars" with a cylindrical glazed shape. Also, the University of Latvia's Academic Training Center for Natural Sciences in Tornakalns, the vertical extension of the glazing of which is extended in a parallelpiped form brings in balance with the nearby landscape space. The silhouette of the National Library of Latvia, designed by the architect Gunārs Birkerts, reminds of the spiritual literary riches. It should be noted that the proportion of the library's glazing in relation to the non-glazed part leaves a bright and light presence of the landscape space in the interior. The presence of the river Daugava and the silhouette of Old Riga is easily and unobtrusively apparent in the reading rooms on all the floors. In turn, the part of the southern facade glazing is raised so as to ensure insulation of the rooms. An essential role in the sphere of space formation art is the game of the entire light, which enters the building volume from the peak of the illusory hill. The Pārventa library in Ventspils has a compositionally powerful solution with a rounded, triangular cylindrical game of shapes, which is integrated into the residential building. The glass facades in the reading rooms and lobby link the indoor with the street plantings. As a vivid example, the new annex of the Academy of Arts, in contrast to the glazed planes, the rough concrete forms of the inclined parallelepiped, which are in contrast with the glazed planes and indirectly
TABLE 1

The study sites in the typological context with the placement in nature [created by the authors, 2017]

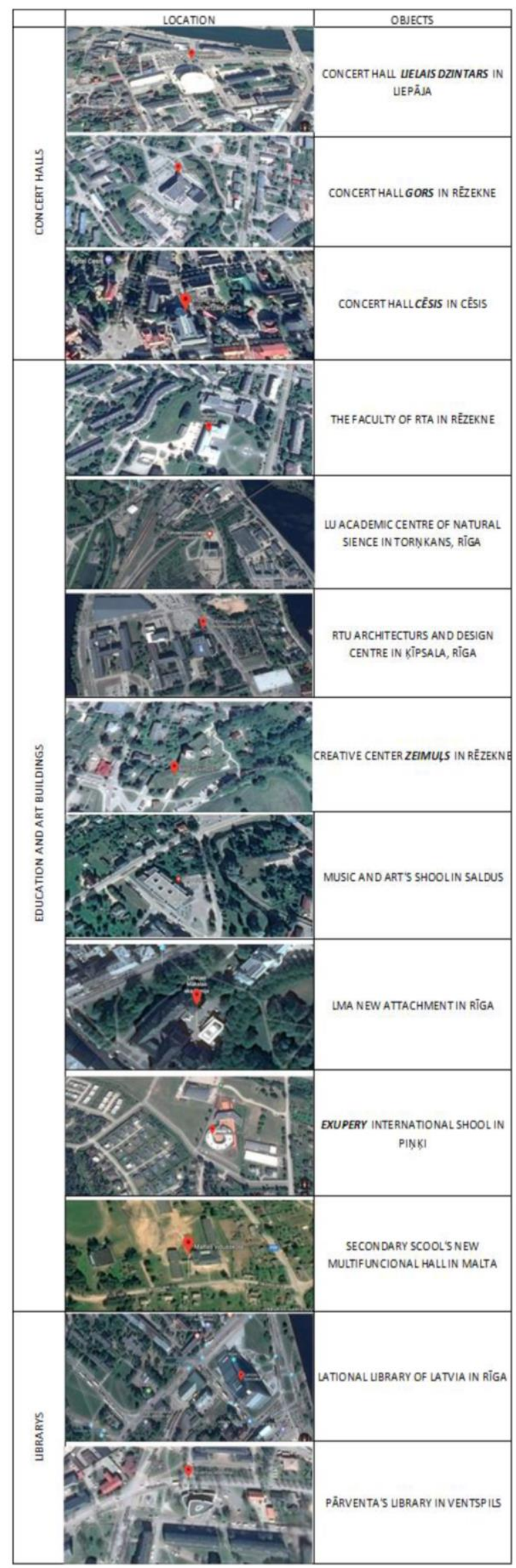


point to the landscape space as a living painting in the corridor's interior. A powerful impression has been achieved by using a ledge leading to the glassed plane that connects the park with the inner space, creating a "painting" in the background of the State Art Museum. In turn, in the upward sight point from the staircase, a "painting" with the sky is readable.

As the second of the criteria, the compositional use of colors and chiaroscuro in interiors was analyzed in the effects of the sunshine. The artistically powerful idea is brought to the orange outer glass planes in the interiors of the concert hall "Great Amber" in Liepāja. Thanks to the sunshine, it brings a surreal character to the interaction between the outer space and the inner space. As the sun moves in its rhythm, all the inner space adjacent to the outer space lights up one by one, thanks to glazing and the shape of the building volume that resembles an overturned, truncated pyramid segment. Due to the sunshine, the mood of the interiors is changing. As seasons change, the silhouette and colors adjacent to the greenery change, which cyclically refreshes the interior with a new colorful mood. The benefits of Latvia's natural beauty in interiors have been successfully used in the interior of the lobby of the Faculty of Engineering at Rezekne Academy of Technologies, in the auditoriums and workshops of Architecture and Design Center of Riga Technical University, in the Rēzekne "Zeimulss" workshops, and in the classrooms and recreation rooms of the Exupery International School in Pinki (Rīga).

As the third of the criteria, the visual accents of the chiaroscuro game were analyzed in the interiors. The newest annex of the Academy of Arts with a passage looking like a tunnel with the light at the end is most prominent in this category. The spatially extended proportions and the rough gray concrete wall finish, as a result of the chiaroscuro game, obtain a more dramatic character that contrasts with the scenic landscape in the outer space.

The fourth criterion that was under the analysis was the semantic correspondence between the outside space and the inner space. The urban landscape space, semantically complementary to the interior, best of all is manifested in projects where artistically high architectural tasks are implemented. Here, we have to mention Liepāja Concert Hall in the diverse urban landscape space, which emotionally engages art life in the urban rhythm and opens the art to the sound of an uproar of the adjoining quarters and streets. The National Library of Latvia should be noted, in the interior of which the silhouettes of Old Riga and the river Daugava semantically magnificently manifest their presence [5]. The academic study center for natural sciences semantically meets the greenery of Tornakalns, mutually complementing each other. The creative center "Zeimuls" on the green, low hill brings a semantic harmony with its natural plastic and serene peace of mind that is needed for creative performers.

As the fifth criterion, the context of the architectural form creation of the site in the landscape space was analyzed. The percentage psycho-emotional quality assessment is used not only for the purpose of a mutual comparison of sites but also for obtaining two-way research results:

- the language of form creation of the landscape space and architecture - the search of the context of the landscape space and the indoor space. The results of the percentage evaluation of the psycho-emotional quality in the gradation from $100 \%$ (for the assessment of the interaction of the destructive interiors and the landscape space) to $+100 \%$ (for the harmonic integration of the interiors with the landscape space assessment) are shown graphically (Fig. 2).

Evaluating each of the above-mentioned sites, in detail, the context of the sites of the landscape space and the architecturally-compositional structure are considered. The workshop rooms of Saldus Art School are visually matched with the space of creative activities located in the outdoor space, which serves not only for art classes but also for the location of expositions. In turn, in the southern part of the space, there is a recreation or relaxation space with loungers and small plantations of small trees. The aforementioned outdoor space of the school is located near the picturesque bank of the river Ciecere, linking the creative activity around the school to the riverbank meadows. A semi-circular landscape space around the school building is formed that spatially unites activities, relaxation, and the ecological core.

A similar harmony of the architectural character and the landscape space is readable in Rezekne Art School "Zeimuls"s". Visually, the overall emotional harmony is created by sloping green roof planes, which expressively complement the side-by-side relief game on the western edge. In turn, on the eastern side of the building volume, there is a bank of the river Rēzekne with separate groups of trees, thus forming a context with its green roofs on the opposite side of the building. With the change in the seasons, tree color, the picturesqueness of the compositional space changes in the main sight points. A very similar compositional change of the landscape space is typical for the building of Faculty of Architecture and Urban Planning of Riga Technical University. Its southern facade is hidden in a birch grove, the foliage of which changes in seasons, each time changing the dark facade finishing. The change of the external image of the 
construction volume creates an intrigue and many facets of both immediate and distant sight points. The simulated plant vein in the facade of the building of Academic Center for Natural Sciences is particularly well readable in the artificial lighting. Visually powerful is the sight point, while in between the building and the green area of the Kileveina ditch: on one side of Vienības gatve - a group of woody plants of the Kileveina ditch but on the opposite side of the street - the facade plant vein desiring to butt together to form a simulated green canal, which brings you into the city. The pronounced symmetry of the building of the Faculty of Engineering of Rezekne Academy of Technologies is increased by a semi-circle front varea with a longitudinal axis where the semi-circle of the eastern edge is introduced by a large group of trees. The Ventspils library, situated in between Tārgale and Ozolu streets, has a wide front square, which is separated from the library building by a dense group of trees. The green tree crown mass creates an intrigue for the perception of two different scales of the urban construction space. The factors of a harmonious interactivity can be divided into three influential basic blocks:

- The quality block of the architectural and compositional environment (the structure of the architectural and spatial planning, the perception of the panorama and silhouette, the semantic relevance of the outdoor and indoor space).

- The block, covering the role and impact of the natural factors on the structures of the architectural design of the urban environment (water basins, the relief, the green system, seasons).

- The block, covering the activity of the gravity field of the urban environment in the settlement system (the factor of the service sector, the factor of attracting tourists, the factor of the cultural and historical heritage).

They are mutually closely linked and in a dynamic interaction. A decisive role in the interaction of multi-factors is played not only by a successful cooperation of specialists but also by the contracting authority, legislation, and engineering communications (Fig. 3).

\section{THE AVERAGE RATING OF LANDSCAPE SPACE AND INDOORS FROM THE PERSPECTIVE OF EXPERT}

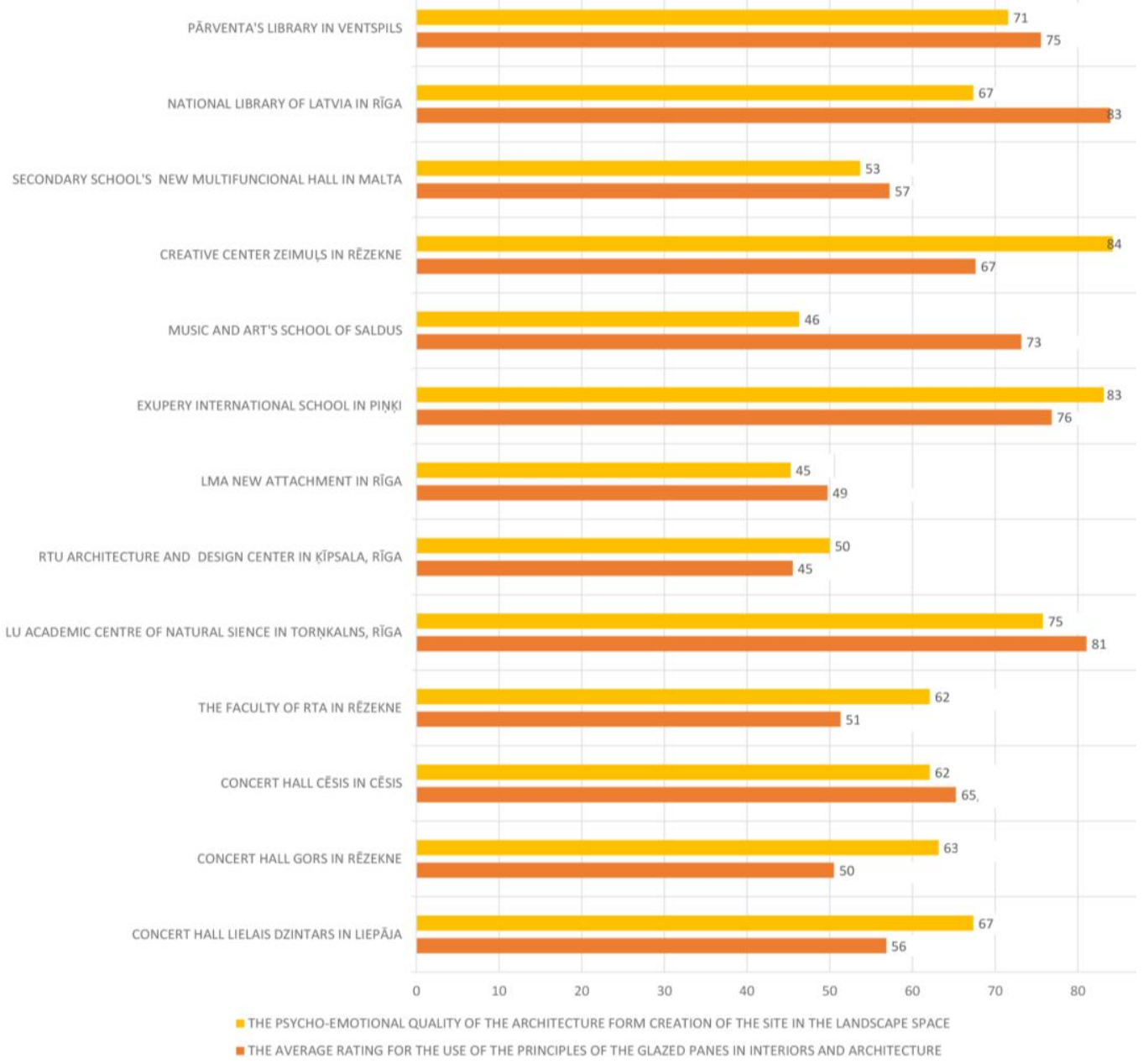

Fig. 2. The mutual comparison of the external and internal criteria creating harmony of the landscape space, architecture, and the interior of various sites [created by the authors, 2017] 


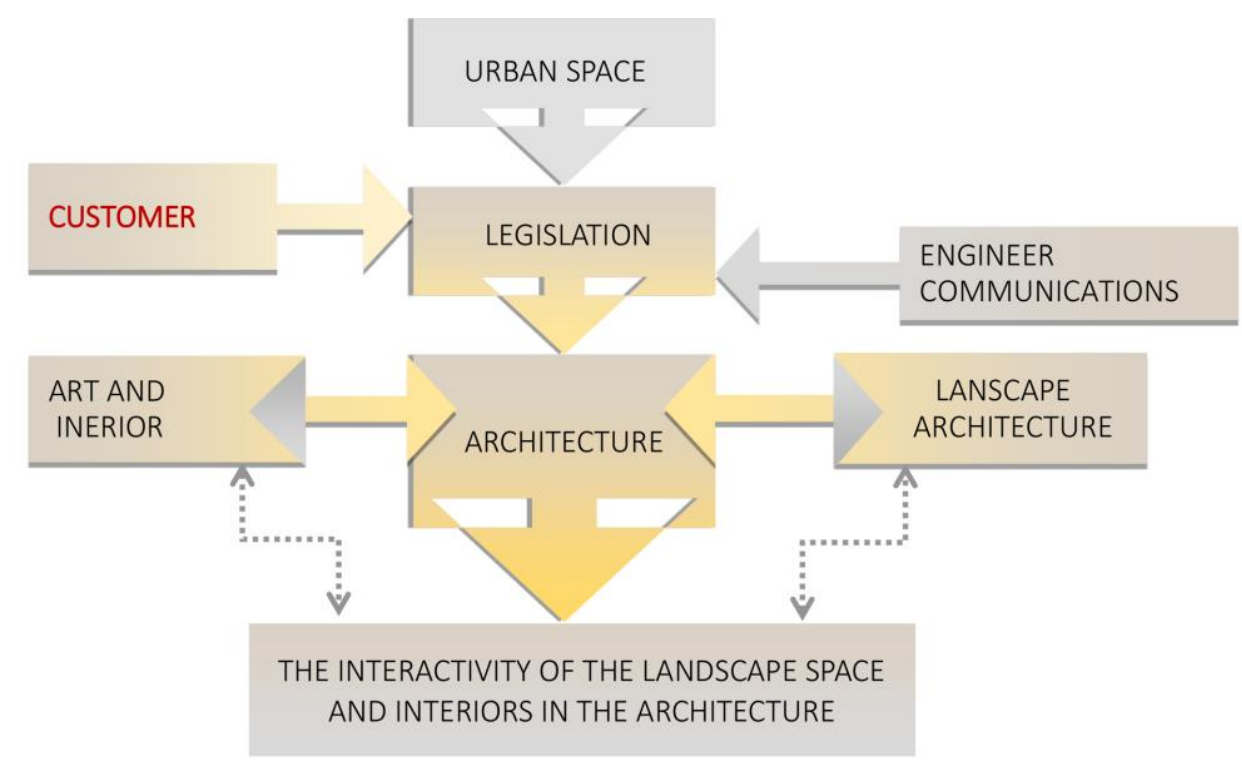

Fig. 3. The aspects forming harmony of the landscape space, architecture, and interior of the urban environment [created by the authors, 2015]

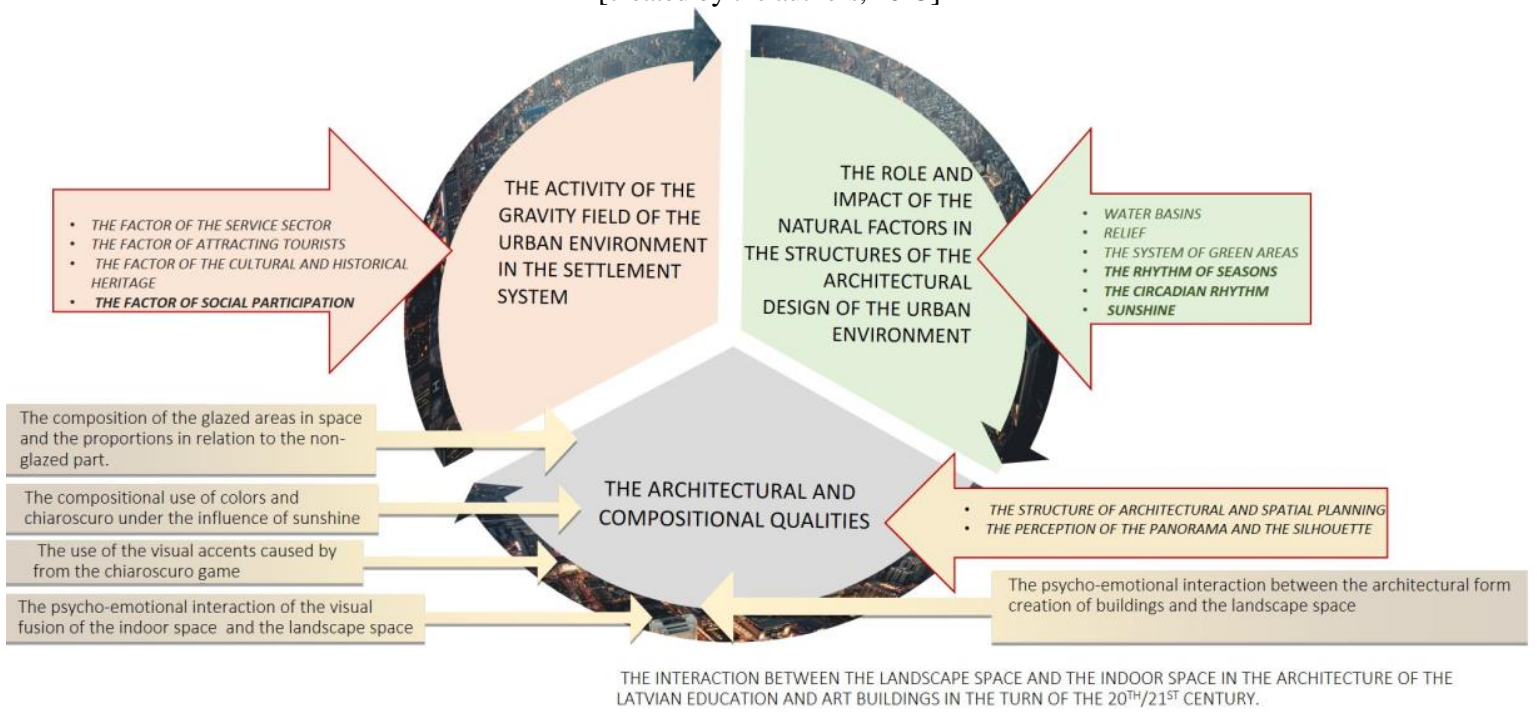

Fig. 4. The criteria of the aesthetic and informative qualities of the art of space creation, consisting of landscape architecture, architecture, and interiors, the author's created, 2017 [according to Brinkis, Buka, 2006; created by the authors, 2017]

\section{Conclusions}

The visual, aesthetic, and psycho-emotional quality of architecture in the landscape space of Latvia and in the architecture of art buildings, linking the interior and the landscape space with widely glazed planes, generally is rated as very good, often showing remarkable results. Excellence in the assessment of the psycho-emotional quality of architecture is reached by sites with integrated, high artistic value, appropriate to the function with the interior and a corresponding landscape space secondary to it.

The results obtained during training at the educational establishments confirm that outdoor and indoor dialog creates a new architecturally landscaped space. The close linking of nature and the interior in the recreational and transit zones is one of the keys of the outdoor and indoor harmony in educational institutions.

In libraries, excellent results can be achieved, combining the light shafts, tunnels, skylights, the reflected light with traditional window planes in facades if the second ones are alternative to the first ones in terms of light intensity.

The study confirms the efforts to find harmony not only with nature in the art of creating the environment but also in the interaction of the landscape space and the indoor space, keeping pace with the scientific developments.

The implementation of the artistically stylistic concept that is alternative at the interdisciplinary level is the most important mission of the environmentalists in the interaction of a harmonious 
landscape space and the indoor space, to which, in turn, the psychologically emotional and material tasks are subordinated. The architectural and spatial proportions in the interaction of the landscape space and the indoor space in an artificial environment, balanced with the ecological core are a powerful tool in attaining high artistic and stylistic objectives in the art of building the environment. The impact of natural conditions on the interaction of the landscape space and the indoor space through the game of chiaroscuro, sunlight, and color, in an artificially created environment is vitally important and appropriate to use in attaining high artistic and stylistic objectives in the art of building the environment and raising the psycho-emotional quality of architecture.

\section{References}

1. Alle, E. Mūsdienu māksla Latvijas kultūrainavā [tiešsaite]. Promocijas darbs Arhitektūras doktora (Dr. arch.) zinātniskā grāda iegūšanai ainavu arhitektūras apakšnozarēe LLU [skatīts 08.19.2016]. http://llufb.llu.lv/promoc_darbi.html?i=promoc_darbi_freims.html\&c=Alle

2. Spriṇge A. Arhitektūra, kas sasilda un atvēsina pilsētas. Saruna ar arhitektu Jakobu Kureku [tiešsaite]. Pastaiga. [skatīts 10.12.2017]. http://jauns.lv/raksts/pastaiga/262714-arhitektura-kas-sasilda-un-atvesina-pilsetas-saruna-ararhitektu-jakobu-kureku

3. Briṇķis, J. Reǵionālās attīstības arhitektoniski telpiskie aspekti. RTU Zinātniskie raksti: 10. Sērija: Arhitektūra un pilsētplānošana. Rīga: RTU, 2007, 1. sēj., 101.-109. lpp.

4. Grietēna, A. Glass as means of indoor/outdoor communication in architecture. Scientific Journal of Latvia University of Agriculture. Landscape Architecture and Art. Jelgava: LLU, 2015, Vol. 6, Nr 6, p. 58-67.

5. Grietēna, A. Study of Harmony in the Indoor / Outdoor Context of Architecture from G. Birkerts at the new building National Library of Latvia. Scientific Journal of Latvia University of Agriculture. Landscape Architecture and Art. Jelgava: LLU, 2014, Vol. 5, p. 48-57.

6. Jencks, C. Architecture becomes music [online]. Architectural Review, May 2013. Vol. 233, p. 91-108. [cited 7.12.2013] http://web.ebscohost.com.ezproxy.llu.lv/ehost/detail?vid=5\&sid=e7587d84-8bc1-4686970139967f6fbea5\%40sessionmgr114\&hid=4212\&bdata=JnNpdGU9ZWhvc3QtbGl2ZQ\%3d\%3d\#db=asu\&AN=87 467917

7. Jencks, C. God, the Architect of the Universe - Universe, the Architect of God [online]. Center: Architecture \& Design in America, 2010. 19 p. [cited 4.12.2013]. https://ezproxy.llu.lv/login?qurl=http://web.ebscohost.com $\% 2$ fehost $\% 2$ fdetail\%3fvid\%3d8\%26sid\%3de7587d84-8bc1-4686-970139967f6fbea5\%2540sessionmgr114\%26hid \%3d121\%26bdata\%3dJnNpdGU9ZWhvc3QtbGl2ZQ\%253d\%253d\#db=asu\&AN=82876453www.1lu.lv

8. Jencks, C. The New Paradigm in Architecture [online]. Architectural Review, February 2003. Vol. 213, p. 72-77. [cited 6.12.2013] https://ezproxy.llu.lv/login?qurl=http://web.ebscohost.com\%2fehost $\% 2 \mathrm{fdetail} \% 3 \mathrm{fvid} \% 3 \mathrm{~d} 7 \% 26 \mathrm{sid}$ \%3de7587d84-8bc1-4686-9701-39967f6fbea5\%2540sessionmgr114\%26hid\%3d121\%26 bdata\%3dJnNpdGU9ZWhvc3QtbGl2ZQ\%253d\%253d\#db=asu\&AN=505047624

9. Strautmanis, I. Dialogs ar telpu. Rīga: Liesma, 1977, 136 lpp.

10. Strautmanis, I. Dzīve arhitektūrāa. Rīga, RTU izdevniecība, 2007, 137 lpp.

11. Strautmanis, I. Māksla arhitektūrāa. Rīga: Liesma, 1982, 103 lpp.

12. Visu gadu uzvarētāji [tiešsaite]. Latvijas Arhitektūras savienība [skatīts 10.10.2017]. https://www.latarh.lv/gadabalva/visu-gadu-uzvaretaji/

13. Ziemeḷniece, A. Context seeking of cultural heritage and green struckture in urban environment. Scientific Journal of the Latvia University of Agriculture: Landscape Architekture and Art. Jelgava: LLU, 2012. Vol. 1, p. 67-73.

14. Zigmunde, D. Estētiskās kvalitātes kritēriji urbanizētas ainavas izpētē. LLU Raksti: LLU Arhitektūras un būvniecības katedra. Jelgava: LLU, 2010, 25 (320), 1.-12. lpp.

15. Zigmunde, D. Latvijas urbānās un lauku ainavas estētiskā un ekologiskā mijiedarbe. Promocijas darba kopsavilkums. Jelgava: LLU, 2010. 84 lpp.

16. Большакова, И. Современные проблемы объединение внешних и внутренних пространств [online]. «Архитектон: известия вузов», № 42, приложение, сентябрь 2013 [cited 10.02.2015]. http://archvuz. $\mathrm{ru} / 2013 \_22 / 70$

17. Власов, В. Дизайн - архитектура и 21. век [online]. «Архитектон: известия вузов» № 41, март 2013 [cited 10.02.2015]. http://archvuz.ru/2013_1/1

18. Гликин, Я.Д. Методы архитектурной гармонии. Ленинград: Стройиздат, Ленинградское отд., 1979. 95 стр.

19. Швидковский, О.А. Гармония взаимодействия. Москва: Стройиздат, 1984. 279 стр.

\section{INFORMATION ABOUT AUTHORS:}

Aija Grietēna graduated in Architectural Sciences - Master of Architecture and Planning. At 2012 Aija Grietēna started Doctoral studies in Latvia University of Agriculture. E-mail: aijagrietena@ gmail.com Aija Ziemelniece, Dr.arch., Professor at the Faculty of Environment and Civil Engineering, Department of Landscape Architecture and Planning of the Latvia University of Agriculture, 22 Liela iela, Jelgava, Latvia, LV-3001. E-mail: aija@k-projekts.lv

Una İle, Dr. arch., Assist. Prof. (since 2012) at the Faculty of Environment and Civil Engineering, Department of Landscape Architecture and Planning of the Latvia University of Agriculture, 22 Liela iela, Jelgava, Latvia, LV-3001. E-mail: una.ile@1lu.lv 
Kopsavilkums. Darba teorētiskā un praktiskā nozīme ir psihoemocionāli harmoniskākas un augstvērtīgas telpiskās vides veidošana Latvijā, kvalitatīvāk sadarbojoties arhitekturas, ainavu arhitektūras un interjeru speciālistiem. Veiksmīgi sadarbojoties ainavu arhitektiem, arhitektiem, interjeristiem un dizaineriem, ir radīta virkne mākslinieciski augstvērtīgus vides objektus, kam raksturīga vides viengabalainība jeb veselums, tādējādi fragmentāri uzlabojot pilsētbūvnieciskās ainavtelpas kvalitāti. Latvijas un starptautiskiem ekspertiem sadarbojoties, šai ziņā īpaši novērtētas trīs koncertzāles, divas bibliotēkas, astoņas izglītības ēkas.

Vizuāli estētiskā un psihoemocionālā arhitektūras kvalitāte Latvijas ainavtelpā izglītības un mākslas ēku arhitektūrā, kopumā vērtējama kā l,oti laba, nereti uzrādot izcilus rezultātus. Izcilību arhitektūras psihoemocionālās kvalitātes vērtējumā sasniedz objekti ar integrētu, funkcijai atbilstošu augsti māksliniecisku vērtību.

Izglītības iestāžu pētījumā iegūtie rezultāti apstiprina, ka ārtelpas un ainavtelpas dialogs veido jaunu risinājumu meklējumu virzienu. Dabas pamatnes elementu un arhitektūras formveides cieša sasaiste rekreācijas un tranzīta zonās ir viena no harmonijas atslēgām izglītības iestādēs. Ainavtelpas turpinājums iekštelpā mākslas un izglītības ēkās ir iegūstams, kombinējot gaismas šahtas, tuneḷus, virsgaismas, atstarotās gaismas ar tradicionālām logu plaknēm fasādēs, ja otrās pakārtotas pirmajām gaismas intensitātes ziņā.

Pētījums apstiprina centienus rast harmoniju ne tikai ar dabas elementiem vides veidošanās mākslā, bet arī ainavtelpas un ēkas arhitektūras mijiedarbē ejot kopsolī ar zinātnes sasniegumiem. Māslinieciski stilistiskās koncepcijas realizācija, kas pakārtota vizuāli estētiskās kvalitātes uzdevumam starpdisciplinārā līmen̄̄, ir svarīgākais vides veidotāju virsuzdevums iepriekš minētajai mijiedarbei, kurai pakārtoti psiholog̣iski emocionālie un materiālie uzdevumi. Arhitektoniski telpiskās proporcijas ainavtelpā, kas sabalansētas ar dabas pamatni, ir spēcīgs līdzeklis augstu mākslinieciski stilistisku mērķu sasniegšanā vides veidošanas mākslā. Dabas elementu konteksta meklējumi, gaismēnu spēle, izsauļojums, gadalaiku kolorīts un kokaugu dendrologiskās īpatnības ir nozīmīgs un lietderīgi izmantojams kritērijs, kas veido svarīgu lomu arhitektūras psihoemocionālās kvalitātes celšanā. 